\title{
Critical Exploration of Indian Economic Reforms of 1991: a lesson for Developing Economies
}

\author{
Ashutosh Kolte, Dario Siggia, Nitin B.Veer, Ashish Daryani
}

\begin{abstract}
The purpose of this research is to examine the impact of reforms that took place in Indian economy in 1991. Balance of payment difficulty resulted in acute economic crisis and therefore economic reforms were inevitable. Post this incident; there have been three more phases of economic reforms. Economic reforms were compelled due to international pressure of the situation post balance of payment crisis of 1991. The significance of this study lies in the derivation of various ways in which these reforms played a major role in the transformation of Indian economy in the form of its impact on poverty, education, socio-cultural mixture, economic growth etc. We have tried to revisit situation of payments crisis and tried to understand if these reforms were enough and were they concrete measures to tackle long-term problem or if they were only sufficient to handle the crisis. Finally we have tried to find out, as to what was left out of reforms or what other measures could have been taken. Balance of payment difficulties are difficulties faced by most of the underdeveloped or developing countries.
\end{abstract}

Keywords : Globalization; Economic Reforms; Devaluation; Privatization; Economic Liberalization; Balance of Payment Crisis; India.

\section{INTRODUCTION AND PRE-1991 ECONOMIC SITUATION: A CONTEXT}

Prior to the rise of Soviet Union, principle of Laissez-faire was followed by the Western economies with high importance attached to the role of private investment in the economy. With the increasing adoption of Marxist policy post World-War 2, the planned economy became a staple across many countries, especially developing countries that were concerned with the fact that opening up to foreign investment might lead to an indirect form of economic domination under Western countries. However, by the 1970s, the world witnessed convincing proofs. The socialist countries were inclined to follow capitalist development strategy because their economic rate of growth was stagnating. These instances gave rise to 'Washington Consensus'.

These terms refer to the broad view of privatization adopted by many developing countries in the 1980s that used

Revised Manuscript Received on July 22, 2019.

Ashutosh Kolte, Assistant Professor, Department of Management Sciences (PUMBA),Savitribai Phule Pune University, India expert at University of Palermo \& Formerly, Policy Adviser at European Parliament, Belgium

Nitin B.Veer, Tilak Maharashtra University, India

Ashish Daryani, Oriental Bank of Commerce, India
Dario Siggia, Italian Ministry of the University and Research, Subject

to follow planned economy models. Opposition parties in these countries heavily criticized the ruling parties for acting as pawns of International Monetary Fund and World Bank. It must be noted that as observations suggest there were no significant differences in the growth rates of countries over long term after adopting privatization compared to the period of government intervention. Also it must be remembered that post Great Depression, John Maynard Keynes suggested 'strong state intervention' which helped mitigate economic crisis of Euro-American countries. By 1991, India realized that neither of the two extremes -Washington consensus or the state-led planned economy - were the appropriate strategies for growth. Whereas, India being at one extreme of this scale adopted liberalization to move towards a mixed economy approach. India witnessed intense Balance of Payment Crisis in 1991 due to various reasons mainly due to inherent weakness in the economy. Economic reforms were mainly carried out to bailout country from Balance of Payment Crisis. Media and many scholars have supported and few raised questions over suitability of the reforms and if some other concrete measures could have been taken to deal with situation.

\section{LITERATURE REVIEW}

Mathew (2006) presents the view that economic reforms generated gains as well as losses and that the losses would be concentrated among a particular group and hence be more noticeable whereas the gains would be diffused and thus less visible. He also stressed that the immediate impact reforms on employment in India was positive and that the rise of small and marginal land holdings over the years after 1991 cannot be attributed as ill effects of reforms.

Saez (2004) contests the aforementioned view stating that India experienced moderate levels of economic growth and attracted modest levels of foreign direct investment even after pursuing similar economic policies as compared to China, one of the largest recipients of foreign direct investment. He also gives the comparison as to whether economic reform could be achieved by gradual social reforms or through revolution citing the context of 1997 East Asian financial crises.

The rise of middle class can be indentified with the success of economic reform is the perspective of Fernandes (2006) who has called for an analysis of the rise of middle class in order to increase the depth of our understanding of the political 
dynamics of economic reforms.

Political sustainability of economic reforms has been brought to attention by Jenkins (1999) by presenting the argument about the notion that, democracy in developing countries restricts politicians from implementing far-reaching reforms, must be addressed. He also highlights the lack of studies in the domain of politics of economic reforms for developing countries like India. Universal entitlement of subsidies that was continued after economic reforms were criticized by Joshi and Little (1996) arguing that these subsidies are being used for covering inefficiencies of Food Corporation of India. According to their perspective, a more targeted approach would be better suited for poverty alleviation as compared to universal entitlement of fertilizer subsidies that do not benefit the very poor.

Hsu (2016) highlights the impact of Nehruvian socialism post-Independence with the focus being on capital accumulation and savings. She also brings attention to the failure of redistribution of land among farmers during the 1950 s and the criticism that this policy attracted. Hope, Kochar, Noll and Srinivasan (2013) highlight the development of industrial licensing in post-Independence India under Nehru where scale, technology, and location of projects were controlled with approval of government being required to initiate, expand, relocate, and change the input or output of industries. The book highlights the restrictions that were put to access domestic equity markets and debt finance and the way in which import licensing, price control and capital issues control gave protection to producers in "priority industries".

Labor reforms still remain the unfinished agenda of the first wave of economic reforms as per Jenkins (2004). He highlights the fact that a complete overhaul of labor laws with specific rules that govern the way employees are hired and fired and human resource dispute resolution mechanism remain long overdue in the eyes of the World Bank, with the perception being that as the Indian economy becomes more globalized and becomes a part of global supply chain, its restrictive labor laws were found not suitable.

An interesting inquiry was conducted by Soo (2006). He conducted the inquiry as to what extent does the prediction of neoclassical model hold, in an economic environment where the government is a major stakeholder with considerable interventions given that the neo classical model assumes that the economy is free from government intervention. This inquiry was conducted in the context of India with special emphasis on the manufacturing sector.

Tovar and Bown (2011) brought to attention the significance of industry level users that used practices such as antidumping tariffs during the 1988-2004 period, citing examples of chemical manufacturers and came to the conclusion that users of these policies, face significant competition from imports and that usage of these policies, potentially distorts activities and incentives in Indian economy.

Dasgupta (2001) criticized Jenkins (2000) by stating that the understanding about democracy, deregulation and corruption remain poorly understood especially for a country like India due to the immense scale of its diversity. The partial privatization of a number of public sector banks and financial institutions, entry of private banks, mutual funds, and other financial intermediaries, cutback in statutory liquidity ratio and cash reserve ratio, adoption of Basel norms and setting up of Securities and Exchange Board of India, are highlighted by Rakshit (2009) as important touchstones of 1991 reform process.

Ghosh (2012) conducts analysis to test the assumption that states with better infrastructure attract more investment and the divergence between states with regard to inequality preand post- 1991 economic reforms.

The way in which public sector banks became source of low-cost finance for the Indian government in the pre-1991 period is described by Kar and Mandal (2014). They highlighted that since India adopted a system of administered interest rates, this led to credit rationing. Analysis by Dreher, Nunnekamp and Vadlamannati (2013) have given the results that endowment of human capital, risk, market size, financial market development and previous international experience in relative terms affects the interaction of foreign investors in India to considerable extent.

After literature review, we arrived at few research questions as below:

i. To what extent economic reforms were successful?

ii. Were these concrete steps to address all economic issues? What reforms were actually needed and what was left out?

\section{RESEARCH METHODOLOGY, OBJECTIVES}

In this study, we have collected data from Reserve Bank of India's website, various publications of government organizations and scholarly publications in the journals. Our study is primarily based on secondary data and focuses on the comparison of economic situation in India in 1990s. The paper presents preliminary findings, and because the research at this stage is in initial phase, the paper is essentially descriptive in nature.

The choice of using secondary data based research methodology can be justified due to the nature of the primary data. The data sourced from World Bank reports is well organized and supports comparison between different nations for different time periods which for this analysis is the period between 1991 and 2011. In our opinion this research offers a basis for empirical development and practical applications. The methodology of this paper also acts as a limitation and hence it is suggested that practical verification of the findings via field investigations would help to refine the parameters involved.

\section{REVISITING ECONOMIC CRISIS}

\subsection{Balance of Payment Crisis of 1991:}

According to (Reddy, 2006), Indian GDP was facing crisis related to payments of debt which was $3.1 \%$ of GDP in 1991.Fiscal deficit was also 
high during this period and inflation rate was increasing day by day. Some biggest enterprises had taken short term external loan at lower market rate, which causes fluctuations in interest rates and devaluation of rupee. Higher amount has to pay in service debt.

Indian credit rating was downgraded by many international credit rating agencies (Taneja \& Thakijrta, 1990). If we look at the Standard and Poor's rating in May 1991, which was also downgraded India's sovereign rating to junk status (Johnson, 2007). Because of this, generating more loans became very difficult. India tried several times on different occasions to raise the foreign exchange from monetary fund but failed to raise foreign exchange from international monetary fund. There was strong pressure on Indian economy to change current monetary policy to raise the loan. Even though, Credit rating was low, no one was willing to extend loans to India without reform in current policies. In 1991, there was lowest confidence in the foreign investor about India's investment policies. Deposits kept by Non Resident Indians suddenly started moving out of country in March 1991 from India. Falling foreign currency assets, rising fiscal deficit, high inflation, and so these deposits started moving out of country in 1991 and in several Non Resident Indians were losing confidence in Indian economy. Further falling of foreign currency assets has started.

Economic crisis could have been expected much earlier as a result of reduce in foreign exchange reserves from USD 3.1 billion in August 1990 to USD .98 billion in July 1991 argued by Reddy. Countries import depended on how much foreign exchange reserve the country holds. Similarly, India witnessed constant reduction in exchange. India had I billion dollar foreign reserve in the exchange, which would have been exhaust in few weeks. (Reddy, 2006).

\begin{tabular}{|l|l|l|l|l|l|l|l|}
\hline \multicolumn{7}{|c|}{ Table-1: Foreign Exchange Reserves in Selected Countries } \\
\hline & & & & & \multicolumn{3}{l|}{ (USD billion) } \\
\hline & 1990 & 1991 & 1992 & 1993 & 1994 & 1995 & 1996 \\
\hline India & 1.21 & 3.58 & 5.46 & 9.81 & 19.39 & 17.47 & 19.74 \\
\hline China & 28.59 & 42.66 & 19.44 & 21.2 & 51.62 & 73.58 & 98.85 \\
\hline Indonesia & 7.35 & 9.15 & 10.18 & 10.99 & 11.82 & 13.31 & 15.06 \\
\hline Malaysia & 9.33 & 10.42 & 16.78 & 26.81 & 24.89 & 22.95 & 25.21 \\
\hline South Korea & 14.46 & 13.31 & 16.64 & 19.7 & 25.03 & 31.93 & 32.32 \\
\hline Thailand & 13.25 & 17.29 & 20.01 & 24.08 & 28.88 & 35.46 & 38.03 \\
\hline Taiwan & 35.79 & 40.28 & 43.53 & 44.3 & 43.38 & 40.87 & 40.1 \\
\hline Import Cover in Months & & & & & & \\
\hline India & 0.6 & 2.1 & 2.8 & 5.2 & 8.7 & 6.1 & 6.7 \\
\hline China & 6.5 & 8.2 & 3.1 & 2.5 & 5.4 & 6.8 & 9.2 \\
\hline Indonesia & 4 & 4.2 & 4.5 & 4.7 & 4.4 & 3.9 & 4.4 \\
\hline Malaysia & 3.8 & 3.4 & 5.1 & 7 & 5 & 3.5 & 3.9 \\
\hline South Korea & 2.5 & 2 & 2.4 & 2.8 & 2.9 & 2.8 & 2.9 \\
\hline Thailand & 4.8 & 5.5 & 5.9 & 6.3 & 6.4 & 6 & 6.5 \\
\hline Taiwan & 7.8 & 7.7 & 7.2 & 6.9 & 6.1 & 4.7 & 4.6 \\
\hline
\end{tabular}

(Ministry of Finance, 1997)

India's foreign Exchange reserve were only USD 1205 million in 1990 and was USD 3580 million in 1991. These Foreign Exchange Reserves were not enough to make payments and imports for longer period of time. Situation was such that India had foreign exchange reserves only to pay for 0.6 months and 2.1 months of imports in 1990 and 1991 respectively. Many other Asian countries had good foreign exchange reserve and balance of payment situation. India witnessed lower reserves and lower import cover than China, Indonesia, Malaysia and Thailand. (Kolte \& Simonetti, A contrary view on Indian Economic Crisis of 1991, 2018)

\subsection{Reasons for Economic Crisis of 1991:}

Russia was one of important trade partner of India. USSR was one the exporter who was exporting oil and defense equipments to India. In a decade before 1990, heavy fiscal deficit, economic crisis, and political instability in USSR led to the fall of USSR. India witnessed steep fall in import form USSR and newly formed Russia. USSR had divided into several countries, most GDR merged in Germany. Due to this reason, India's important trade partners were facing issues in their own economies led to fall in trade and further fall in Foreign 


\section{Critical Exploration of Indian Economic Reforms of 1991: a lesson for Developing Economies}

Currency Assets.

Indian economy was not fully open to the foreign enterprises and strict regulation, licensing for domestic businesses. Balance of trade was always negative for India. Inefficient economy and high balance of payment made the situation further critical for India. Similarly, Rise in oil prices due to Gulf war and devaluation of Rupee several times resulted in costlier imports and ultimately high inflation.

USSR cancelled rupee trading agreement due to the Political and Economic Crisis of USSR of late 1980's and its severity at the beginning of 1990's, stalled oil supply from USSR. Devaluation of Rupee, rise in oil prices and economic and political crisis in USSR created situation for India to jump in its import Bill. If we compare current economic situation of India with 1980's, economy was doing well and steady. Economy started growing post 1980's much above so called 'Hindu Growth Rate'. There was low FCAs for facing external economic jerk. In this condition, smaller jerk caused a balance of Payment crisis for the country, what bigger jerk could have done? (Bhagwati, 1993) (Panagariya, 2004). During pre liberalization period of Indian economy, reforms began slowly in 1980. Liberalization policy increased the import to country in 1980 but FCA's kept reducing as consequence of continuous negative balance of trade. (Kolte \& Simonetti, A contrary view on Indian Economic Crisis of 1991, 2018)

Indian economy was liberalized initially in 1980 but before the liberalization period, there were various trade restrictions on import and export of goods. India could have balanced the situation by creating investment friendly policies for business to minimize import and increase export. There was possibility to export the several cheap and quality manufactured goods in the post domestic economic reforms, which could have helped post trade liberalization to correct the Balance of Trade.

In 1980, Economy was structurally weak to meet foreign economic jerks. Prime Minister P V Narasimha Rao is the pioneer of the liberalization, privatization, globalization model, which worked as deterrence against Balance of Trade problem. Practically, Indian economy was still strong enough after reforms. Ongoing payment crisis and to improve many aspects of the economy was the measure concern of ongoing reforms. Reforms were undertaken to deal with the Foreign Currency Assets touching USD 400 billion, which indicates that the Indian economy is not strong yet and yet not ready to deal with world economic crisis. (Kolte \& Simonetti, A contrary view on Indian Economic Crisis of 1991, 2018)

Raising fund is difficult, if country or economy get low credit ration score. Even, Ease of doing business and difficult bureaucracy in likening the business was India's measure concern. In this situation, it is very difficult to raise the funds to finance payment crisis. Gulf war and in anticipation of problems with Indian economy, NRI deposits had eroded in 1991. Due to low ratings it was very difficult to raise funds to finance payment crisis. These factors restricted expansion in foreign exchange reserves. Chandra Shekhar government could not make any policy decision to improve trade and foreign exchange reserve. Finally, Government of India had to agree on advice of Reserve Bank of India to pledge country's gold to foreign banks to facilitate the pavement for the trade. (Kolte \& Simonetti, A contrary view on Indian Economic Crisis of 1991, 2018)

Many economists pointed out those internal weaknesses of economy like low productivity, inflation, fiscal deficit are not responsible for payment crisis of 1991 but there was international, political and economic instability in western countries that gave jolts and was responsible for balance of payment crisis of 1991.

Indian economists and policy makers had no prior idea or inputs on the fall of USSR economy, OPEC Policies, changing commodity prices, economic problems in USSR, and unification of GDR into Germany, Gulf politics, and internal economic inefficiency. India changed its trade and an economic policy under the direction of IMF. India's own interest was not evaluated properly by domestic policy makers, which resulted in India to devaluate the exchange rate. Country had only option to reforms the current economic and trade policy conditionally to fight economic crisis. (Kolte \& Simonetti, A contrary view on Indian Economic Crisis of 1991, 2018)

\subsection{Various generations of economic reforms}

Regulated economy has changed to the market based economy after reforms. During 2000 to 2001, first generation economic reforms operationlized which helped the private sector.

Private sector was heavily promoted. Many reforms were made during this period. State owned monopoly abolished on manufacturing sector to promote private enterprises. MRTP limit and Phased production were abolished. De-licensing and de-reservation of industries was done, which resulted in removal of government restriction on certain businesses. Environmental laws were simplified. Efforts were taken to make the public sector undertakings profitable and efficient by using joint venture with foreign partners to look it globalized economy. Quantitative restrictions on import were abolished and exchange rate was also switched to floating rate. Full current account convertibility and tax reforms were introduced to simplify tax compliance, and check tax evasion. Foreign Exchange Management Act was replaced with FEMA.

In the first generation economic reforms had some limitations. Those are restriction on petroleum sector, heavy duty or levy on sugar production. Due to those limitations, expected result were not achieved and forced to implement second generation reforms. Second generation of economic reforms were implemented from 2000-01 onwards. International joint ventures, free leverage of the capital market, greenfield ventures, introduction of greater tax devolution for the states are just some of the types of steps 
taken during this period of time. Contradictory and Outdated laws were abolished. Reforms were introduced in the Indian Penal Code by passing bills in the assembly. FRBM act was passed by the parliament. Social inclusion reforms were introduced to focus on education and health during this phase.

In the Tenth plan (2002-2007), third generation of economic reforms introduced. Measure focuses are of this generation reforms were the Panchayati Raj Institution and on its full functionality. Every strata of the society has been targeted to reach socio-economic benefits to grassroots. The Eleventh Plan continues on same focus area to further strengthen the economy of the country.

The fourth generation reforms are covering all together and include previous phased out sectors. Economist has the opinion that,

fourth generation reforms are based on information technology based reforms to reach all portion of the beneficiary area of the nation.

\section{EFFECTS OF ECONOMIC REFORMS AND ANALYSIS OF DATA}

We have studied implication of reforms on various aspects in the economy like, Literacy, poverty, education, health,

Table-II Poverty, education, sanitation and health from 1980 to 2000:

\begin{tabular}{|c|c|c|c|}
\hline \multirow{2}{*}{ Indicator } & \multicolumn{3}{|c|}{ Reported date } \\
\hline & $1980 \mathrm{~s}$ & $1990 \mathrm{~s}$ & 2000 \\
\hline $\begin{array}{l}\text { Poverty: } \\
\text { Poverty incidence (\%) }\end{array}$ & 44.5 & 36.0 & 26.1 \\
\hline \multicolumn{4}{|l|}{ Demographics: } \\
\hline Population (millions) & 685 & 846 & 1,027 \\
\hline Population growth (\%) & 2.2 & 1.9 & 1.6 \\
\hline Overall sex ratio, ages 0-6 (females per 1,000 males) & 978 & 955 & 927 \\
\hline \multicolumn{4}{|l|}{ Education: } \\
\hline Overall literacy rate: $7+$ years $(\%)$ & 44 & 52 & 65 \\
\hline Female literacy rate as percent of male literacy (5) & 53 & 61 & 71 \\
\hline Net enrolment rate (NER): grades $1-5(\%)$ & 47 & 51 & 77 \\
\hline Female NER as a percent of male: grades $1-5(\%)$ & 70 & 80 & 81 \\
\hline \multicolumn{4}{|l|}{ Health: } \\
\hline Life expectancy at birth (year) & 56 & 60 & 61 \\
\hline Infant mortality rate, $0-12$ months (per 1000 live births) & 115 & 79 & 68 \\
\hline Under-five mortality rate (per 100,000 live births) & 152 & 94 & 95 \\
\hline Malnourished children, ages 0-3 (\%) & n.a. & 53 & 47 \\
\hline Maternal mortality rate (per 100,000 ) & n.a. & 424 & 540 \\
\hline Prevalence of HIV (million people) & n.a. & 3.5 & 4.0 \\
\hline \multicolumn{4}{|l|}{ Environmental Sustainability: } \\
\hline Access to improved water source $(\%)$ & n.a. & 68 & 78 \\
\hline Households with toilet facility $(\%)$ & n.a. & 30 & 36 \\
\hline
\end{tabular}

(World Bank, 2003)

5.2 Employment: Das and Sharma (2011) highlight, suggest through their analysis that FDI in India, 1991, has remained market-seeking and state that with the increase in FDI, employment, national income, external sector and Central Bank functioning etc. To have a better interpretation of the findings, it is necessary to bifurcate the analyzed data into above discussed segments.

5.1 Poverty, education and health: Rajaraman (1996) highlighted that the reforms initiated in India were revolutionary in scale as per Indian standards. However these fell short in comparison to similar reforms that were implemented in other nations. She also stated that there is very little examination with regard to, what might have happened if the pace with which the reforms were implemented would have been faster. The growing importance of the rural consumer was highlighted by Kalirajan and Sankar (2001) stating that with increased connectivity provided by roads and railways, rural marketing to such areas had become progressively easier.

Poverty decreased considerably in this period and access to improved water source increased. The above data supports the conjecture that there is increase in literacy rate, especially among females combined with improved access to water source and sanitation facilities contributing to the reduction in

poverty.

imports have intensified because imports, in the Indian context, are required as inputs for 
domestic and export products. The public servants are paid considerably more than their private counterparts. This issue was not resolved in the aftermath of the economic reforms due to strong push by unions due to which significant burden falls on the fiscal resources of the government to make payment for salaries.

The productivity enhancements as introduced by the developments in IT sector are slowly being adopted by the bureaucratic machinery of the government to streamline governance and thus reduce inefficiency costs. Still bureaucratic expenditure in the form of salary payments remains a major expense for fiscal resources of government.

5.3 GDP growth rate and Public and Private Investment:
The inflation rate has stabilized, the current account balance has declined and the external reserves have increased considerably. The contribution of the private sector as $\%$ of GDP has increased. During the mid-1990s private investment rose due to increased market demand along with the increasing pace of economic reforms but as the pace of reforms slowed down and the expected market demand failed to materialize, the firms found themselves in a situation where they had excess capacity and debt which led to a decline in private investment during the early 2000s.

Table-III: Sector-wise GDP growth rate and other macroeconomic indicators:

\begin{tabular}{|l|l|l|l|l|}
\hline Indicator & $1980 \mathrm{~s}$ & $\begin{array}{l}1992 / 93- \\
1996 / 97\end{array}$ & $\begin{array}{l}1997 / 98- \\
2001 / 02\end{array}$ & $2002 / 03$ \\
\hline GDP growth (\% a year) & 5.6 & 6.7 & 5.5 & 4.4 \\
Agriculture & 3.4 & 4.7 & 1.8 & -3.1 \\
Industry & 7.0 & 7.6 & 8.5 & 6.1 \\
Services & 6.9 & 7.5 & 22.5 & 7.1 \\
Investment rate (\% of GDP) & 22.0 & 23.3 & 6.6 & 22.1 \\
Public & 10.0 & 8.0 & 15.9 & 15.3 \\
Private & 12.1 & 15.3 & 4.9 & 2.5 \\
Inflation (Wholesale Price Index, \% a year) & 8.0 & 8.7 & 9.3 \\
General government deficit (\% of GDP) & 8.1 & 7.2 & -0.7 \\
Current account balance (\% of GDP) & -2.1 & -1.2 & 7.0 \\
External reserves (months of goods and services & 3.3 & 5.9 & & 1.0 \\
imports, end of period) & & &
\end{tabular}

(World Bank, 2003)

\subsection{Performance of External Sector post Economic Reforms:}

As a result of series of events like political instability in the country, gulf war, rising oil prices and fall of USSR, there were negative impact on India's external sector which created crisis of 1991. Imports increased faster than exports. Economic reforms were mainly implemented to deal with economic crisis of 1991 and to get medium term positive outlook towards Indian economy. Balance of Trade and Balance of Payments were adverse and due to low 'net private transfers', 'net invisibles' were negative after several years which resulted in alarmingly low foreign exchange reserves.

Table-IV: Trend in External Sector (Figures in billions USD):

\begin{tabular}{|l|l|l|l|l|l|l|l|l|}
\hline Year & Imports & Exports & $\begin{array}{l}\text { Balance } \\
\text { of Trade }\end{array}$ & Invisibles & $\begin{array}{l}\text { Current } \\
\text { Account }\end{array}$ & $\begin{array}{l}\text { Foreign } \\
\text { Investment } \\
\text { Net }\end{array}$ & $\begin{array}{l}\text { Short External term } \\
\text { Debt }\end{array}$ & $\begin{array}{l}\text { Long } \\
\text { term } \\
\text { External } \\
\text { Debt }\end{array}$ \\
\hline $1985-1986$ & 17.29 & 9.46 & -7.83 & 2.97 & -4.87 & 0.00 & NA & 32.96 \\
\hline $1986-1987$ & 17.73 & 10.41 & -7.32 & 2.76 & -4.56 & 0.20 & NA & 38.06 \\
\hline $1987-1988$ & 19.81 & 12.64 & -7.17 & 2.32 & -4.85 & 0.43 & NA & 42.37 \\
\hline $1988-1989$ & 23.62 & 14.26 & -9.36 & 1.36 & -8.00 & 0.36 & NA & 44.48 \\
\hline
\end{tabular}




\begin{tabular}{|l|l|l|l|l|l|l|l|l|}
$1989-1990$ & 24.41 & 16.96 & -7.46 & 0.62 & -6.84 & 0.41 & 7.50 & 68.36 \\
\hline $1990-1991$ & 27.91 & 18.48 & -9.44 & -0.24 & -9.68 & 0.10 & 8.54 & 75.26 \\
\hline $1991-1992$ & 21.06 & 18.27 & -2.80 & 1.62 & -1.18 & 0.13 & 7.07 & 78.22 \\
\hline $1992-1993$ & 24.32 & 18.87 & -5.45 & 1.92 & -3.53 & 0.56 & 6.34 & 83.68 \\
\hline $1993-1994$ & 26.74 & 22.68 & -4.06 & 2.90 & -1.16 & 4.24 & 3.63 & 89.07 \\
\hline $1994-1995$ & 35.90 & 26.86 & -9.05 & 5.68 & -3.37 & 4.81 & 4.27 & 94.74 \\
\hline $1995-1996$ & 43.67 & 32.31 & -11.36 & 5.45 & -5.91 & 4.62 & 5.03 & 88.70 \\
\hline $1996-1997$ & 48.95 & 34.13 & -14.82 & 10.20 & -4.62 & 5.96 & 6.73 & 86.74 \\
\hline $1997-1998$ & 51.19 & 35.68 & -15.51 & 10.01 & -5.50 & 5.35 & 5.05 & 88.49 \\
\hline $1998-1999$ & 47.54 & 34.30 & -13.25 & 9.21 & -4.04 & 2.31 & 4.39 & 93.29 \\
\hline $1999-2000$ & 55.38 & 38.29 & -17.10 & 12.94 & -4.16 & 5.19 & 4.04 & 94.39 \\
\hline
\end{tabular}

(Planning Commission, 2001)

Table-V: Balance of Payment Important Indicators (in Percentage):

\begin{tabular}{|c|c|c|c|c|c|c|c|c|c|}
\hline \multirow[b]{2}{*}{ Year } & \multicolumn{2}{|c|}{$\begin{array}{l}\text { Import } \\
\text { Export }\end{array}$} & \multicolumn{3}{|c|}{ Invisibles } & \multicolumn{3}{|c|}{ Current Account } & \multirow{2}{*}{$\begin{array}{l}\text { Import } \\
\text { cover in } \\
\text { months }\end{array}$} \\
\hline & $\begin{array}{l}\text { Exp./ } \\
\text { GDP }\end{array}$ & $\begin{array}{l}\text { Imp./ } \\
\text { GDP }\end{array}$ & $\begin{array}{l}\text { Receipts/ } \\
\text { GDP }\end{array}$ & $\begin{array}{l}\text { Payments/ } \\
\text { GDP }\end{array}$ & $\begin{array}{l}\text { Net/ } \\
\text { GDP }\end{array}$ & $\begin{array}{l}\text { Receipts/ } \\
\text { GDP }\end{array}$ & $\begin{array}{l}\text { Receipt/ } \\
\text { Payment }\end{array}$ & $\begin{array}{l}\text { CAD/ } \\
\text { GDP }\end{array}$ & \\
\hline 1985-1986 & 4.1 & 7.5 & 2.8 & 1.5 & 1.3 & 6.8 & 74.8 & -2.1 & 4.5 \\
\hline 1986-1987 & 4.2 & 7.2 & 2.6 & 1.5 & 1.1 & 6.7 & 76.8 & -1.9 & 4.4 \\
\hline $1987-1988$ & 4.6 & 7.2 & 2.6 & 1.8 & 0.8 & 7.0 & 78.6 & -1.8 & 3.8 \\
\hline $1988-1989$ & 4.9 & 8.1 & 2.6 & 2.1 & 0.5 & 7.3 & 71.5 & -2.7 & 2.4 \\
\hline 1989-1990 & 5.8 & 8.3 & 2.6 & 2.3 & 0.2 & 8.2 & 76.4 & -2.3 & 1.9 \\
\hline 1990-1991 & 5.8 & 8.8 & 2.4 & 2.4 & -0.1 & 8.0 & 71.5 & -3.0 & 2.5 \\
\hline 1991-1992 & 6.8 & 7.9 & 3.6 & 2.9 & 0.6 & 10.2 & 94.3 & -0.4 & 5.3 \\
\hline 1992-1993 & 7.7 & 9.9 & 3.8 & 3.0 & 0.8 & 11.3 & 87.7 & -1.4 & 4.9 \\
\hline 1993-1994 & 8.2 & 9.7 & 4.1 & 3.1 & 1.0 & 12.2 & 95.6 & -0.4 & 8.6 \\
\hline 1994-1995 & 8.3 & 11.1 & 4.8 & 3.1 & 1.8 & 13.0 & 91.7 & -1.0 & 8.4 \\
\hline 1995-1996 & 9.1 & 12.3 & 5.0 & 3.4 & 1.5 & 13.9 & 88.8 & -1.7 & 6.0 \\
\hline 1996-1997 & 8.8 & 12.6 & 5.5 & 2.9 & 2.6 & 14.2 & 91.6 & -1.2 & 6.5 \\
\hline $1997-1898$ & 8.7 & 12.5 & 5.7 & 3.2 & 2.4 & 14.2 & 90.9 & -1.3 & 6.9 \\
\hline 1998-1999 & 8.2 & 11.4 & 6.2 & 4.0 & 2.2 & 14.4 & 93.2 & -1.0 & 8.2 \\
\hline $1999-2000$ & 8.3 & 12.3 & 6.7 & 3.8 & 2.9 & 15.0 & 93.0 & -1.0 & 8.2 \\
\hline $2000-2001$ & 9.9 & 12.6 & 7.0 & 4.9 & 2.1 & 16.8 & 96.4 & -0.6 & 8.8 \\
\hline
\end{tabular}

(Reserve Bank of India, 2018)

Table 4 and 5 clearly shows that imports were increased in 1990-91, without substantial increase in exports and invisibles, more particularly private remittances were reduced, reducing net invisibles and net invisibles to GDP. Foreign Currency Assets available for Import cover were very low. As a result of reforms, in 1995-96 import cover increased to 6 months where as in 2000-2001 it increased to 8.8 months, which was a positive effect of reforms. As a result of reforms there was little improvement in trade figures. Balance of Trade dropped to USD 2.8 billion in 1991-92 from USD 9.44 billion in 1990-91. Whereas, net invisibles steadily increased post economic reforms mainly due to rise in Private Transfers by confident Indian Diaspora abroad. Thereafter a boom in the IT and ITES industry resulted into higher and higher revenues for companies and in turn higher contribution in Net invisibles, which resulted into steady accumulation for foreign exchange reserves.

5.5 Central Bank, Capital Reserve Requirements and Financial Stability:

Post 2008 economic crisis, the autonomy of central banks was a major concern in the history of bank autonomy referred (Andew J. (1986). Strong specific reserve requirements significantly influenced bank closings and bank failures (Economopolous, 1986).

Greenbaum and Thakor (1989) argued that the reserve requirement reform in the context of less than striking success of legal reserve requirements in the attainment of 


\section{Critical Exploration of Indian Economic Reforms of 1991: a lesson for Developing Economies}

the traditional goals of provision of liquidity and facilitation of monetary control. Harvilesky and Gildea (1995) did statistical research, which concluded that if the bank presidents were economists, and then they tended to be more reliable in their FOMC voting behavior as opposed to non-economist bank presidents who tended to be swayed by the inclinations of the party in power.

Porter (1983) highlighted how the reserve bank management could be perceived as having an agent-principal relationship with the private individuals that make up the economic system, under the direction of the board. And how, as it is generally considerably costly for these individuals to monitor the reserve bank's performance, the bank is typically not accountable to the real principals- but instead to the government.

Five steps recommended by Hendy \& Evans (1995) that could proceed positively in related to banking autonomy are namely defining charter of the reserve bank, setting an inflation target, composition of reserve bank board, publication of reserve bank board minutes and appearance of governor before a Joint Committee. India also implemented a considerable number of these steps in this direction.

Kanatas and Greenbaum (1982) stated that the efficacy of reserve requirements is maintained if the incentive that it provides for financial innovations is ignored. And that these requirements, may turn out to be counter-productive, if the relevant monetary aggregate is broader than that which is reserve-constrained.

In recent news events, agreement between government and RBI with regard to CCB (capital conservation buffer) norms for the government has become prominent. Kolari, Mahajan and Saunder (1988) suggested two kinds of changes, temporary changes in the reserve requirements for monetary policy and more permanent changes in the reserve requirement levels. As per their analysis they found that temporary changes, as indicated in the recent government and RBI agreement to postpone complete implementation of capital conservation buffer norms to next year, were found to have little effect on security prices, whereas more permanent changes had a stronger influence on bank stock prices, which reflect a tax burden effect.

Recently, the issue of transfer of reserves of the RBI considered, RBI pays surplus to the government by direct balance transfer and monetization of assets. In the absence of the future reduction in government borrowing program, RBI would be burdened to reduce liquidity that would be created due to higher spending by selling government bonds via open market operation. Accordingly, the figure of total sale of government bond by RBI and government would increase in relation to the figure of surplus transfer. Hence, if a government plans to utilize surplus transfer to reduce amount of government bonds sold to public, the intention gets defeated. If the assets of central bank are sold to pay a special dividend, the size of the balance sheet subsequently reduces. As the RBI earns surplus from difference between income from assets and virtually no payment for its liabilities, accordingly, the surplus will get reduced with reduction in size of the balance sheet. Therefore, if a government plans to use the special dividend in order for a reduction in debt, the reduced RBI surplus would offset the reduced interest cost.

\section{DISCUSSION OF RESULTS}

Agrawal, Gokarn, Mishra, Parikh and Sen (1995) argue that although the relationship between money growth and inflation in India was not stable in the past, there is considerable support to the hypothesis that upward trend in inflation during the 1980s had given push to the excessive growth in money supply that has been observed since 1982 . They bring to attention that after the oil shock of 1979-1980, the inflation rate had reverted to the historical average of 6 percent but it increased during the second half of the decade.

During the first generation of economic reforms, the government removed the licensing 'raj', abolished the MRTP limit, reduced non-tariff based trade barriers etc. Private sector firms were promoted and tax reforms were initiated in order to simplify the compliance procedure. Private sector got encouragement and thereafter we could see remarkable contribution of the private sector in the economy. In the process of privatization government also divested its stake in many of its corporations in next few decades. Government diluted its stake in many navratna and mini navratna companies. Funds generated by selling capital assets were not utilized in other productive capital assets. Government utilized most of the divested money, in financing revenue budgets, which was a blunder. Even though there was no emergency and no necessity, divested funds were utilized in annual budgets of government. If place of divesting its stake in companies, government could have improved management, working, technology in these corporations which would have resulted in rise in profits, regular dividends and higher capital appreciation of shares of Corporations.

Securities and Exchange Board of India was established as the markets regulator. However, these set of reforms were not giving results at the desired pace and hence another set of reforms were initiated from 2000 onwards. The Administered Price Mechanism was dismantled because such a system affected the profitability of the firms. Outdated and contradictory laws were abolished. Corporate farming, research and development in agriculture sector and inclusive education and healthcare were promoted. The Fiscal Responsibility Act ushered in the sustainable maintenance of fiscal prudence. The third generation reforms were implemented from the 2002-2007 onwards with the implementation of Panchayati Raj Institutions in order to support the most vulnerable economically weaker communities in the Indian society. The fourth generation of the economic reforms is in continuation now as India aims to become fully information technology enabled. Recent developments in the form of Brexit and Trump administration indicate to protectionist measures being adopted by some Western countries. However, India continues to have a globalist mindset.

The analysis of data supports the conjecture that 
although the reform process implemented in India was not entirely perfect, still it contributed massively to improving the socio-economic status of the masses of the population. Indian economic reforms of 1991 were a major event in the context of Asian socio-economic development that has received the attention from scholars. Tyagi and Bhagwati (1994) highlight the reluctance of Indian economy to take benefit by integrating with the global economic supply chains has garnered considerable attention with the major reason being that Indian economic model was defined by export pessimism.

Many reforms were left out. A point of contention that exists among economists to this date is that many of the economic reforms that are politically contentious, for example, privatization of BSNL etc. have not been done. India has not developed a mature bond market and many large-scale corporate entities are still dependent on banks for financing of term loan and working capital requirements.

\subsection{Have reforms addressed all the important issues?}

Considerably large number of issues such as higher inflation rates, poverty, Health care, and faster growth of GDP were dealt with as a result of economic reforms. Inefficiency in the public sector was reduced and motivated Private sector. As a result of this policy, NRI's gained confidence and started remittances in the country. IT / ITES companies boomed and resulted in creation of large employment of population in the service sector. Contribution of service sector in GDP increased rapidly. Reforms were successful in taking out economy from Payment Crisis and gave positive direction for overall economic growth.

In past few years, fourth generation reforms are being taking place like, creation of Monetary Policy Committee, implementation of Insolvency and Bankruptcy Code, implementation of Goods and Service Tax have addressed a number of pressing concerns. Macroeconomic stability of India in this context is a testament to this.

However, many issues still require appropriate resolutions. We have discussed ahead in this paper the issues which were not addressed by reforms in 1991 and subsequent second, third and fourth generation of reforms.

\subsection{Where Reforms successful? Was something left out of the Reforms?}

There were the positive steps taken by the government and we can see the positive changes in foreign trade, balance of trade, balance of payments, NRI confidence, private remittances, and revenue of service sector which is part of invisibles in the Balance of Payments. We could see growth in Literacy, stability in inflation and rise in national income post reforms. Government did its level beast by liberating trade and promoting SEZ's, IT / ITES Industries which led to quantum jump in Foreign Currency Assets over period of time.

But researchers are of opinion that no concrete steps were taken to address long term economic vulnerability. Issues were mainly dealt with short term and medium term perspective. Major economic, political and administrative reforms are required for tackling this economic vulnerability. Economic policy failed to attract higher FDI in coming years. Trade to GDP ratio remained low compared to developing economies. In 2012, India again faced balance of payment difficulties. There was a risk of another crisis, but issue was dealt as there were enough accumulated foreign exchange reserves to deal with the situation. Inefficiency though reduced, remained prominent in the economy. Liquidity support may be a short term remedy to deal with adverse balance of payment situation, but this may not be a permanent solution as we experienced another tough situation in 2012. Long lasting solution for such a situation is economic reforms, which promote a climate of investment that supports development of domestic capabilities so that we as a nation reduce our reliance on imports through substitution and increase exports. Further innovative and concrete measures can help in giving permanent solution to problem of Balance of Payments. (Kolte \& Daryani, A study on India's Balance of Payment difficulties of 2012, 2018). Many things could have been considered in the said economic reforms as discussed in the following points.

Further, reforms are required for adequate capital framework for the central bank, committee structure for other regulators such as SEBI, IRDAI etc. according to the structure of MPC with definite, specifically defined targets and implementation of a new direct tax regime and these prominent reforms are needed to be carried out in the near future in order to sustain the present GDP growth of 7-8 \% and possibly increase this figure in the range of $9-11 \%$ in times of global economic recovery.

\subsection{Researchers believe that following initiatives were required to be taken up long back:}

6.3.1 Restricting Oil Imports: Import of oil has remained a major contributor in creating Balance of Payment deficit. Government should have restricted import of oil by putting additional custom and excise duties, and by making it further costlier for consumption in the domestic market.

6.3.2 Public Transport System: India is urbanizing and large population has kept migrating towards cities in search of employment and better life. Most of the growing cities were not planned to cater this growing population. Those cities which were properly planned, had excluded mass public rapid transport system from their plans. Metro Rails, development of water transport and other modes of mass and rapid transport systems were needed by Indian cities. Rising population in cities with rising income preferred motor cars as a preferable mode of transport in absence of mass rapid transport system, which led to over increasing demand for oil. Very fewer efforts were taken to introduce vehicles running on cleaner sources of energy.

6.3.3 Power deficit: Most of Indian states were power deficit. Absence of electricity during working hours lead to low productivity in factories, low 
productivity of farmers and low productivity of urban working class. Efforts were taken to expand thermal power plants and less efforts were taken to set up sufficient number of nuclear power plants which do not deplete natural resources as fast as power plants consuming oil and coal. Fewer efforts were taken to use renewable energy resources and these proved ineffective. Power deficit leads to import of oil and import of cheap coal to run power plants and factories this leads of addition to Balance of Payments burden. By setting up nuclear power plants, India could have made it power surplus, resulting in improved efficiency of factories, cities and working class.

6.3.4 SEZ Performance was very satisfactory in the recent past, but many SEZ's remained only on paper and companies delayed using SEZ premises for productive purposes. Many SEZ's did not actually function. Many companies looked at SEZ's as a real estate investment opportunity. To protect development rights in the SEZ, companies started units with lower production capacities against expectations. Medical SEZ is a very attractive concept and medical costs in India are low compared to many countries in the world. This should have been taken as an opportunity to establish medical SEZ's. These SEZ's could have been made sustainable by giving tax exemptions on all infrastructure requirements by hospitals and all sort of purchases. Special tax refunds on air tickets and purchases made by foreign visitors in the medical SEZ could have been introduced. This effort would have generated additional foreign exchange for the country.

6.3.5 Rise in employment level and improvement in the productivity of the working class: By introducing a sophisticated human resource system government could have worked on employment for all and compulsory employment for certain number of hours for all in certain age groups. Efforts should have been taken to improve productivity of human resource at work.

6.4 Few innovative ideas which can help to deal with payments difficulties: Reforms of 1991 were forced by circumstances and were mainly targeted to deal with the Balance of Payment crisis by stimulating various factors in the economy. Though these stimulations in terms of economic policy worked, there were further possibilities which could have been given serious thought.

We have discussed few innovative ideas as a remedy to long term difficulties of Balance of Payment and so that further possibility of payment crisis can be eliminated. Firstly, possibility of Rupee Trading Area in South Asia, South East Asia and Gulf should be explored. Secondly, possibility of Economic Union of South Asia and introduction of its own currency can be explored. Thirdly, BRICS economies are emerging economies and contribute large portion of World GDP. These are developing economies and are expected to grow at a faster rate in the future also. It is expected that these economies will have dominate over world economies in the coming decades. And this gives an opportunity for BRICS economies to form stronger trade blocks or economic unions. Concept of BRICS Bank which resulted in the formation of New Development Bank (NDB), can have stronger mechanism to support countries in need of foreign exchange. NDB can have its own BRICS currency, just like SDR of IMF. Currency of NDB can be floated on proportionate reserve system or can have decentralized central banking system. This will help BRICS economies to shield itself from economic and political influence of foreign economies and will help them to put a halt to domestic economic turmoil. Fourthly, Non hard currency settlement agreements will help underdeveloped and developing countries to trade freely in domestic or other foreign currencies, which will not lead to serious Balance of Payment crisis in these economies. And Finally, Barter trade agreements can be signed by developing and underdeveloped economies for barter trade. In barter trade there is possibility of balance of payment surplus /deficit and this balance of payment surplus or deficit with the said country can be adjusted in the subsequent years.

\section{CONCLUSION}

India is a highly populated country and has a large economy. After independence of India, there was a sluggish growth in the economy. Even after lot of efforts economy could not attain higher GDP growth rate. In 1980's efforts were taken to modernize economy, which resulted into technology / capital imports. Thereafter, there was a gulf war, crisis in USSR and political instability in the India. These factors resulted into deterioration of economic condition further and India met with payment crisis. Economic reforms were triggered by payment crisis of 1991 . Economic reforms were taken up to improve Indian economy as a whole and were popularly known a Liberalization, Privatization and Globalization (LPG) policy of the government. After critically evaluating policy we found that there were positive implications of policy of 1991 on Indian economy in terms of GDP growth, Literacy, stabilized inflation, betterment in health care facility, improvement of productivity of workforce, rise in income level etc. Private sector was highly motivated by the policy. There was a boost of IT/ITES industry. International community and Indian Diaspora abroad gained faith in Indian Economy which resulted in economic boom in the coming years. But this policy could have addressed the root cause of the crisis which was 'Foreign Currency Assets' and could have taken few concrete measures to deal with this. We have discussed few things which were not dealt with effectively, like restricting oil imports, development of massive public transport system in cities, alternative sources to curb power deficit, higher employment and controlling performance of SEZ's. We have also discussed few innovative ideas, like development of rupee trading area, Economic Union of South Asia and Gulf, common monitory unit by BRICSs countries by establishing BRICS Central 
bank or through NDB, promotion of trade in non hard currencies, barter trade agreements which can help developing economies to deal with payment difficulties. Economic reforms effectively dealt the crisis on 1991, but better steps could have been taken to make economy stronger as discussed above.

\section{REFERENCES}

1. Agrawal, P., Gokarn, S. V., Mishra, V., Parikh, K. S., \& Sen, K. (1995) Economic Restructuring in East Asia and India - Perspectives on Policy Reform. Macmillan Press Ltd.

2. Bhagwati, J. (1993). India in Transition: Freeing the Economy. Oxford University Press

3. Das, R. K., \& Sharma, C. (2011). FDI, Trade and Growth Dynamics: New Evidence from the Post-Reform India. The International Trade Journal 233-266.

4. Dreher, A., Nunnenkamp, P., \& Vadlamannati, K. C. (2013). The Role of Country of Origin Characterstics for Foreign Direct Investment and Technical Cooperation in Post-Reform India. World Development, 88-109.

5. Economopolous, A. J. (1986). The Impact of Reserve Requirements on Free Bank Failures. Atlantic Economic Journal , 76-84.

6. Fernandes, L. (2006). India's new middle class : democratic politics in an era of economic reform. The University of Minnesota Press.

7. Ghosh, M. (2012). Regional Economic Growth and Inequality in India during Pre and Post Reform Periods. Oxford Development Studies , 190-212.

8. Greenbaum, I. S., \& Thakor, V. A. (1989). Bank Reserve Requirements as an Impediment to Signaling. Economic Inquiry , 75-91.

9. Havrilesky, T., \& Gildea, J. (1995). The Biases of Federal Reserve Bank Presidents. Economic Inquiry, 274-284.

10. Hendy, P., \& Evans, G. (1995). Reserve Bank Independence: Still on the Agenda. Journal of Applied Economics and Policy , 50-61.

11. Hope, N. C., Kochar, A., Noll, R., \& Srinivasan, T. N. (2013). Economic Reform in India - Challenges, Prospects and Lessons. Cambridge University Press.

12. Hsu, S. (2016). Economic Reform in Asia- China, India and Japan. Edward Elgar Publishing Limited.

13. Jenkings, R. (2004). Labor Policy and the Second Generation of Economic Reform in India. India Review.

14. Jenkins, R. (1999). Democratic Politics and Economic Reform in India. Cambridge University Press.

15. Johnson, J. (2007, January 31). India's sovereign credit rating upgraded. New Delhi. Retrieved from https://www.ft.com/content/714d6a02-b0b0-11db-8a62-0000779e2340

16. Joshi, V., \& Little, I. (1996). India's Economic Reforms. Clarendon Press Oxford.

17. Kalirajan, K. P., \& Sankar, U. (2001). Agriculture in India's Economic Reform Program. Journal of Asian Economics, 383-399.

18. Kanatas, G., \& Greenbaum, S. I. (1982). Bank Reserve Requirements and Monetary Aggregates. Journal of Banking and Finance, 507-520.

19. Kar, S., \& Mandal, K. (2014). Re-Examining the Finance-Growth Relationship for a Developing Economy-A time series analysis of Post-Reform India. The Journal of Developing Areas , 83-105.

20. Kolari, J., Mahajan, A., \& Saunder, E. M. (1988). The Effect of Changes in the Reserve Requirements on Bank Stock Prices. Journal of Banking and Finance, 183-198.

21. Kolte, A., \& Daryani, A. (2018). A study on India's Balance of Payment difficulties of 2012. International Journal of Research in Social Sciences, $8(6(1)), 511-516$.

22. Kolte, A., \& Simonetti, B. (2018). A contrary view on Indian Economic Crisis of 1991. International Journal of Creative Research Thoughts , 6 (1), 54-64.

23. Mathew, E. T. (2006). Employment and Unemployment in India. Sage Publications Inc.

24. Ministry of Finance. (1997). Economic Survey of India 1997: External Sector. New Delhi: Ministry of Finance, Government of India.

25. Panagariya, A. (2004). Growth and Reforms during 1980s and 1990s . Economic and Political Weekly

26. Planning Commission. (2001). Indian Planning Experiance A statistical Profile. Planning Commission, Planning Commission. New Delhi: Planning Commission, Government of India.

27. Porter, M. (1983). The Reserve Bank and Financial Liberalisation. Journal of Applied Economics and Policy, 166-176.

28. Rajaraman, I. (1996). Book Review of India: The Future of Economic Reform. Journal of Development Economics , 489-492.
29. Rakshit, M. (2009). Macroeconomics of Post-reform India. Oxford University Press.

30. Reddy, Y. V. (2006, December 19). Dynamics of Balance of Payments in India. Hyderabad, Andhra Pradesh, India. Retrieved from https://rbidocs.rbi.org.in/rdocs/Speeches/PDFs/74785.pdf

31. Reserve Bank of India. (2018). Balance of Payments - Indicators, Handbook of statistics on Indian economy. Mumbai: Reserve Bank of India.

32. Saez, L. (2004). Banking Reform in India and China. Plagrave Macmillan.

33. Soo, K. T. (2008). From Licence Raj to Market Forces: The Determinants of Industrial Structure in India after Reform. Economica .

34. Taneja, S., \& Thakijrta, P. (1990, October 31). International credit rating agencies downgrade India's county rating. Mumbai, India. Retrieved from https://www.indiatoday.in/magazine/economy/story/19901031-internati onal-credit-rating-agencies-downgrade-india-country-rating-813183-19 90-10-31

35. Tovar, P., \& Bown, C. P. (2011). Trade liberalization, antidumping, and safeguards: Evidence from India's tariff reform. Journal of Development Economics .

36. Tyagi, S., \& Bhagwati, J. (1994). The Giant Awakens. The Columbia Journal of Business .

37. World Bank. (2003). India, Sustaining Reform, Reducing Poverty. I world bank policy developement review. New Delhi: Oxford University Press.

38. World Bank. (2003). India, Sustaining Reform, Reducing Poverty. World Bank. New Delhi: Oxford University Press 